International Trade 


\title{
International Trade: Causes and
}

\section{Consequences}

An Empirical and Theoretical Text

\author{
J. Borkakoti \\ Principal Lecturer in Economics \\ Centre for Research in International Economics \\ Middlesex University
}

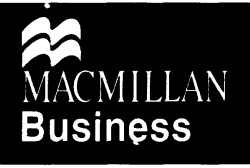


C) Jitendralal Borkakoti 1998

Softcover reprint of the hardcover 1st edition 1998 978-0-333-72555-9

All rights reserved. No reproduction, copy or transmission of this publication may be made without written permission.

No paragraph of this publication may be reproduced, copied or transmitted save with written permission or in accordance with the provisions of the Copyright, Designs and Patents Act 1988, or under the terms of any licence permitting limited copying issued by the Copyright Licensing Agency, 90 Tottenham Court Road, London W1P 9HE.

Any person who does any unauthorised act in relation to this publication may be liable to criminal prosecution and civil claims for damages.

The author has asserted his right to be identified as the author of this work in accordance with the Copyright, Designs and Patents Act 1988.

First published 1998 by MACMILLAN PRESS LTD Houndmills, Basingstoke, Hampshire RG21 6XS and London Companies and representatives throughout the world

ISBN 978-0-333-72556-6

DOI 10.1007/978-1-349-27014-9

A catalogue record for this book is available from the British Library.

This book is printed on paper suitable for recycling and made from fully managed and sustained forest sources.

$\begin{array}{rrrrrrrrrr}10 & 9 & 8 & 7 & 6 & 5 & 4 & 3 & 2 & 1 \\ 07 & 06 & 05 & 04 & 03 & 02 & 01 & 00 & 99 & 98\end{array}$


This book is dedicated to my mother, with fond memories 


\section{Contents}

Preface

$\mathrm{XV}$

1 Introduction 1

2 International Trade in the Real World and the

Theoretical Issues

8

2.1 Introduction 8

2.2 Country specific data on the pattern of international trade

2.3 The UK pattern of trade 13

$\begin{array}{lll}2.4 & \text { The subject matter of pure theory } & 16\end{array}$

3 Economic Methodology 18

3.1 Introduction 18

3.2 Method of enquiry in economics 18

3.3 Approaches to scientific episteme 21

3.4 Methods of appraising competing theories 22

3.5 Role of assumptions à la Friedman 23

3.6 Economic theory and economic policy 26

4 The Classical View: Specialisation and Exchange, Absolute and Comparative Advantage $\quad 28$

4.1 Introduction 28

4.2 The Mercantilist doctrine 29

4.3 Adam Smith 31

4.4 David Ricardo, James Mill, Robert Torrens 34

4.5 Friedrich List 39

4.6 John Stuart Mill 41

4.7 Summary and comments $\quad 45$

5 Sources of International Trade: An Overall View 49

5.1 Introduction 49

$\begin{array}{lll}5.2 & \text { International price differential } & 49\end{array}$

5.3 Factor endowments and productivity 50

5.4 Human capital, scale economies and R\&D expenditure 51

5.5 Product and process innovation 51

5.6 Availability of products $\quad 52$

5.7 Product differentiation and market structure 52 
$6 \quad$ The Ricardian Hypothesis $\quad 54$

6.1 Introduction 54

6.2 The assumptions 55

6.3 The autarkic equilibrium 56

6.4 The pattern of specialisation 59

6.5 International trade and the equilibrium terms of

6.6 The offer curve analysis 61

6.7 Biased demand: a case of incomplete specialisation 62

6.8 Dissimilar country size: a case of incomplete specialisation

64

6.9 The many-goods case $\quad 65$

6.10 The many-country case 67

6.11 The Ricardian model mathematically treated 68

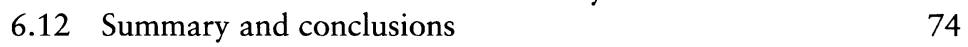

7 Empirical Tests of the Ricardian Hypothesis 77

$\begin{array}{lll}7.1 & \text { Introduction } & 77\end{array}$

7.2 The MacDougall study 78

7.3 The Stern and the Balassa studies 83

7.4 The Kreinin study 86

$\begin{array}{lll}7.5 & \text { The Sailors-Bronson study } & 87\end{array}$

7.6 The McGilvray and Simpson test 88

$\begin{array}{ll}7.7 & \text { The Bhagwati critique } \\ 7.8 & \text { Some }\end{array}$

$\begin{array}{lll}7.8 & \text { Some observations } & 91\end{array}$

7.9 Summary and conclusions 93

8 The Heckscher-Ohlin Hypothesis $\quad 97$

$\begin{array}{ll}8.1 \text { Introduction } & 97\end{array}$

8.2 The assumptions 98

8.3 The autarkic equilibrium 101

8.4 The pattern of specialisation 106

8.5 Proof of the HOS theorem 109

8.6 International trade and the equilibrium terms of trade $\quad 110$

$\begin{array}{ll}\text { 8.7 The offer curve analysis } & 112\end{array}$

8.8 The Baldwin diagram 113

8.9 Stability of the international equilibrium 116

$\begin{array}{ll}8.10 & \text { Summary and conclusions } \\ & 122\end{array}$

9 The Heckscher-Ohlin Model Mathematically Treated 125

9.1 Introduction $\quad 125$

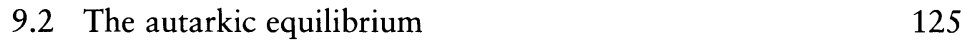

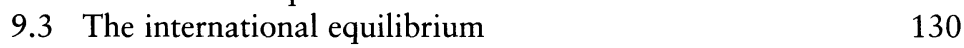

9.4 The Jones model 135

9.5 Summary and conclusions 139 
10 Some Extensions of the Simple HOS Model

10.1 Introduction

10.2 Internationally non-identical tastes

10.3 Internationally non-identical technology

143

10.4 The reversal of factor intensities

10.5 The two-factor two-country many-good case

10.6 The two-good two-country many-factor case

149

10.7 The two-good two-factor many-country case

10.8 Summary and conclusions

150

11 Two Comparative Static Theorems 152

11.1 Introduction 152

11.2 The Stolper-Samuelson theorem 152

11.3 The SS theorem mathematically treated 156

11.4 The factor-price equalisation theorem 158

11.5 The FPE theorem mathematically treated 162

11.6 More on the FPE theorem 164

11.7 Summary and conclusions 165

12 The Ricardo-Viner Model 168

12.1 Introduction 168

12.2 The Ricardo-Viner model 168

12.3 Factor-specificity and the Stolper-Samuelson theorem 171

12.4 International trade 173

12.5 A mathematical version of the Ricardo-Viner model 175

12.6 Summary and conclusions 176

13 Empirical Tests of the HOS Hypothesis:

The Factor Content Studies 177

13.1 Introduction 177

13.2 The Leontief paradox 178

13.3 The Leontief-type studies of other countries 181

13.3.1 The Tatemoto-Ichimura study 182

13.3.2 The Bharadwaj study 183

13.3.3 The Roskamp study 184

13.4 Further Leontief-type studies on the US 185

13.4.1 The Baldwin study 185

13.4.2 The Stern-Maskus study 186

13.5 The HOV model 188

13.6 The Leamer critique and the Leontief paradox 189

13.7 The Bowen-Leamer-Sveikauskas study 192

13.8 The Trefler studies 194

13.9 Summary 197

13.10 Conclusions 200 
14 Empirical Tests of the HOS Hypothesis:

The Cross-Section Studies 203

14.1 Introduction 203

14.2 The cross-commodity studies 204

14.2.1 The Baldwin study 204

14.2.2 The Branson-Junz study 205

14.2.3 The Harkness-Kyle study 206

14.2.4 The Branson-Monoyios study 207

14.2.5 The Harkness study 208

14.2.6 The Stern-Maskus study 209

14.2.7 The Stern study 210

14.3 Criticisms of the cross-industry regression method 211

14.4 The cross-country regression studies 212

14.4.1 The Balassa cross-country study I 212

14.4.2 The Baldwin cross-country study 213

14.4.3 The Bowen study 213

14.4.4 The Balassa cross-country study II 215

14.5 Summary 216

14.6 Conclusions 219

15 Empirical Tests of the HOS Hypothesis:

The Tests of Assumptions 226

15.1 Introduction 226

15.2 The Minhas test of nonreversibility of factor intensities 226

15.3 An empirical test of homothetic preferences 229

15.4 An empirical test of the assumption of internationally identical production functions $\quad 230$

15.5 Summary and conclusions 231

16 Two Theorems in Comparative Statics:

The Rybczynski Theorem and the Findlay-Grubert Theorem 233

16.1 Introduction 233

16.2 The Rybczynski theorem 233

16.3 Movement of the terms of trade 236

16.4 The Rybczynski theorem mathematically treated 237

16.5 The Findlay-Grubert theorem 239

16.6 The Findlay-Grubert theorem mathematically treated 243

16.7 Summary and conclusions 246

17 International Trade and Economic Growth 249

17.1 Introduction 249

17.2 Neutral and biased growth 249

17.3 The elasticity theorem 252

17.4 Movement of the terms of trade and welfare implications 254 
17.5 Impact of economic growth on the terms of trade and volume of trade

17.6 Immiserising growth

17.7 Summary and conclusions

18 Trade and Growth Mathematically Treated

18.1 Introduction

18.2 The case of capital accumulation 263

18.3 The case of technological progress 267

18.4 Summary and conclusions

272

19 A Dynamic Model of Capital Accumulation and International Trade

19.2 The model 276

19.3 The temporary equilibrium 277

19.4 The $A_{\min }(k)$-curve and the $A_{\max }(k)$-curve 278

19.5 Division of the $k^{B}-k^{A}$ plane into specialised and non-specialised regions

19.6 Some comparative static results

19.7 Dynamics of capital accumulation 284

19.8 Summary and conclusions 290

20 The Neofactor Proportions Theories 292

20.1 Introduction 292

20.2 The human-capital hypothesis 293

20.3 The skill-intensity hypothesis 297

20.4 The R\&D hypothesis 299

20.5 The scale-economies hypothesis 300

20.6 Multiple-regression models 301

20.7 Summary and conclusions 307

21 The Neotechnology Theory of International Trade 313

21.1 Introduction 313

21.2 The dynamic trade advantage 314

21.3 A model with process innovation 317

21.4 The Krugman model with process innovation 318

21.5 A model with product innovation 322

21.6 The Krugman model with product innovation 327

21.7 The product cycle hypothesis 331

21.8 Models with endogenous innovations 333

21.9 Summary and conclusions 334

22 Empirical Tests of the Neotechnology Hypothesis 338

22.1 Introduction 338 
22.2 Leads and lags 339

22.3 A test of the product cycle hypothesis 340

22.4 The Soete test of the neotechnology theory 341

22.5 The Hufbauer test of the neotechnology theory 344

22.6 R\&D effort as a test of the neotechnology theory 345

22.7 Summary and conclusions 346

23 Views on Synthesis of the Neofactor Proportions and Neotechnology Hypotheses $\quad 350$

23.1 Introduction 350

23.2 Relative strengths of the hypotheses 351

23.2.1 The Wolter study 351

23.2.2 The Hirsch study 354

23.2.3 The Goodman-Ceyhun study 357

23.3 Synthesis of the hypotheses 358

23.4 Summary and conclusions 361

24 The Linder Hypothesis 366

24.1 Introduction 366

24.2 The Linder hypothesis 366

24.3 Per capita income as a basis for trade 369

24.4 Empirical tests of the Linder hypothesis 370

24.5 Summary and conclusions 374

25 Intra-Industry Trade: Imperfect Competition, Increasing

Returns to Scale, and Product Differentiation 377

25.1 Introduction 377

25.2 Definition and measurement of IIT 378

25.3 General features of the IIT models 379

25.4 The Krugman model 384

25.5 The Lancaster model 388

25.6 The Falvey model 393

25.7 The Brander-Krugman model 394

25.8 Summary and conclusions 398

26 Empirical Studies in Intra-Industry Trade 402

26.1 Introduction 402

26.2 Documentary studies 403

26.3 The econometric tests 405

26.3.1 The Loertscher-Wolter study 405

26.3.2 The Toh study 408

26.3.3 The Greenaway-Milner study $\quad 410$

26.3.4 The Hughes study 413

26.4 Empirical significance of the explanatory variables 
26.5 Problems of testing intra-industry trade models 418

26.6 Summary and conclusions 419

27 Endogenous Growth and International Trade 423

27.1 Introduction $\quad 423$

27.2 Integrated world equilibrium 424

27.3 The Grossman-Helpman model 428

27.4 The DOS model 435

27.5 Empirical tests of knowledge spillovers 444

27.5.1 The Coe-Helpman study 445

27.5.2 The Branstetter study 448

27.5.3 Brief outlines of other studies $\quad 450$

27.6 Summary and conclusions 451

28 Gains from Trade $\quad 456$

28.1 Introduction 456

28.2 Gains from trade and the Ricardian hypothesis 457

28.3 Gains from trade and the HOS hypothesis 459

28.4 Gains from trade and the utility-possibility frontier 461

28.5 Gains from trade and the revealed preference theory $\quad 463$

28.6 Feasibility of lump-sum transfer and the DixitNorman theorem 466

28.7 Domestic distortions and gains from trade 468

28.8 Gains from trade and the initial international price differential

469

28.9 Gains from trade and the neotechnology theory with process innovation

28.10 Gains from trade and the neotechnology theory with product innovation

28.11 Gains from trade and intra-industry trade $\quad 473$

28.12 Gains from trade and adjustment problems $\quad 476$

28.13 Summary and conclusions $\quad 478$

29 Trade Policy 483

29.1 Introduction 483

29.2 The instruments of trade policy 483

29.3 A microeconomic analysis of the welfare effects
of tariffs, quotas and subsidies

29.4 The general equilibrium effect of a tariff 489

29.5 Domestic distortions, tariffs and subsidies 493

29.6 The infant-industry argument for protection 496

29.7 Trade policy and intra-industry trade 499

29.8 Strategic trade policy 502

29.9 Trade policy and the neotechnology theory 
29.10 Trade adjustment policies

29.11 Summary and conclusions

30 Economic Integration

30.1 Introduction

30.2 Forms of economic integration

519

30.3 The partial equilibrium theory of customs union

520

30.4 The general equilibrium theory of customs union

523

30.5 The Kemp-Wan theorem

525

30.6 Imperfect competition and customs union

526

30.7 Summary and conclusions

Appendix 1 Community Indifference Curves 530

Appendix 2 On the Relative Price 534

Appendix 3 Trade Indifference Curves 536

Appendix 4 The Offer Curve 538

Appendix 5 Derivation of Demand Functions from the CobbDouglas Utility Function

Appendix 6 Factor Endowments:

Physical and Price Definitions $\quad 549$

Appendix 7 Walras's Law

550

Appendix 8 The Meade Diagram 552

Appendix 9 On Local and Global Stability 556

Appendix 10 The Input-Output Model 559

Appendix 11 The HOV Model 564

Appendix 12 An Extension of the Rybczynski Theorem 566

Appendix 13 Generalised Rybczynski Theorem 567

Appendix 14 Generalised Findlay-Grubert Theorem 570

Appendix 15 An Analysis of Trade and Capital Accumulation in the Labour-Abundant Country 572

Appendix 16 The Impact of Capital Accumulation on the

Reciprocal Demand Function $\quad 574$

Bibliography $\quad 576$

Author Index $\quad 591$

Subject Index $\quad 595$ 


\section{Preface}

We ought to be neither like spiders which spin things out from their insides nor like ants which merely collect but like bees which both collect and arrange.

Sir Francis Bacon (1561-1626)

With the wisdom encapsulated in Bacon's saying as the guiding principle of this book, I endeavour to incorporate the above maxim by placing equal emphasis on the theories of international trade and their empirical tests.

I have been teaching international trade as part of an international economics module since the early 1970s. The body of knowledge in both international trade and international money has expanded rapidly during the last twenty-five years. As a consequence, it has become increasingly difficult to cover the apposite contents of both trade theory and international money in one book. This is reflected in the currently used textbooks in international economics, where either the empirical studies in trade theory or the new trade theories of the 1980s usually receive perfunctory treatment. It probably is the right time to accept the natural line of division between trade theory and international money and to teach these subjects as separate modules with the intellectual rigour each subject area richly deserves.

The objective of this book is to bring together theoretical and empirical studies scattered over the pages of learned journals and books, in a manner which emphasises the tenets of economic methodology. It is useless to have some abstract economic theories if these cannot be applied to analyse the real world problems. Therefore, it is as important to study the empirical work in trade theory in rigorous detail as it is to learn the abstract trade theories in rigorous depth. In this book a theory is followed by its empirical tests in strict accordance with economic methodology.

The theoretical exposition is carried out in terms of both geometry and mathematical functions. It is well known that trade theories use fairly complicated diagrams; and a diagram can be a very powerful tool of analysis. Mathematical models are mostly counterparts of geometrical analysis, and a reader can skip the mathematical models if he or she so chooses, without any loss of orthodox theoretical knowledge. But there are exceptions. The model which deals with dynamic capital accumulation and the models which deal with endogenous growth cannot be understood without some knowledge of calculus and differential equations. I should also mention that without some mathematical knowledge it will be difficult to 
understand the new models dealing with intra-industry trade and the dynamic models dealing with process and product innovations.

The book is aimed at Final Year BA/BSc undergraduate students but the MA/MSc graduate students will also benefit from it. The reader's knowledge of microeconomics and econometrics is assumed to be of Year 2 undergraduate level. The mathematical models can be understood if the reader is familiar with calculus and matrix algebra. A reader with Year 2 level of mathematics for economists should be able to cope fairly easily. It is obvious from the various new developments in trade theory that one has to have knowledge of intermediate level microeconomics, mathematics for economists, and econometrics in order to achieve a clear understanding of the empirical and theoretical work in modern trade theory.

This book can be used either to teach the trade part of international economics or to teach a full module in international trade. Chapter 1 suggests how to do this with a menu of choices of chapters and sections.

I would like to take this opportunity to thank my colleagues Paul Dunne, Len Gomes, Alan Gully, Harry Hillier and Dirk Willenbockel for useful discussions. I also wish to thank Alan Winters who commented on some of the earlier chapters and Peter Sinclair who commented on some of the later chapters. I found their comments very useful. I am most grateful to Chris Milner who patiently read the whole manuscript and sent comments and suggestions which led to definite improvements in several chapters. Needless to add, I am solely responsible for errors and omissions that may remain in the book. I have reproduced verbatim two small theorems, namely, the Dixit-Norman theorem and the Kemp-Wan theorem. I am grateful to the authors and to Cambridge University Press for granting permission for the former, and to Elsevier Science for the latter. I also wish to thank Andrew Ramsden for research assistance; and Dina Junior Manda for word-processing the final manuscript.

Last but not least, I wish to express my gratitude to my wife and my children for their love, support and patience during the long periods of enforced isolation that was necessary to complete this book. 